\title{
Histopathological Study of a Mummified Eye and Optic Nerve from a Strangled Peruvian Mummy
}

\author{
Jordi Esteban $^{a}$ Sandra Cases-Mérida ${ }^{a}$ Montserrat Tortosa ${ }^{a}$ Berta Marzal ${ }^{a}$ \\ Arabel Fernández ${ }^{c}$ Cesar Gálvez ${ }^{c}$ Regulo Franco ${ }^{c}$ Pedro Luis Fernández ${ }^{a}$ b \\ ${ }^{a}$ Department of Pathology, Hospital Clínic, and b University of Barcelona, Barcelona, Spain; ' $\mathrm{C} A C E B$ - Museum of Cao \\ (Fundación Augusto N. Wiese), Lima, Peru
}

\section{Established Facts}

- Mummified individuals are very difficult to study from a forensic and histopathological point of view due to tissue degradation.

- Ocular structures are easily damaged and rarely found in mummies.

\section{Novel Insights}

- Rehydration allows the histopathological study of mummified tissues, and eye structures such as eyelids, sclera, the optic nerve, and periorbital fat can be recognized after the mummification process.

- Optic nerve hemorrhage can help to establish strangulation as the cause of death in mummified subjects.

\section{Key Words}

Paleopathology · Mummy · Eye · Optic nerve hemorrhage ·

Strangulation

\section{Abstract \\ We present the histopathological findings of a naturally mummified eye from the Peruvian Lambayeque culture (900-1,200 AD), in which rehydration, light microscopy, and scanning electron microscopy allowed a detailed analysis of several eye tissues including the eyelids, sclera, and optic}

nerve, the latter showing evidence of hemorrhage likely related to the documented strangulation as the cause of death. We conclude that histopathological analysis of rehydrated mummified tissues can provide valuable information from fragile eye structures including the optic nerve, and these findings can be useful from a forensic point of view.

(C) 2015 S. Karger AG, Basel

\section{KARGER 125}

(c) 2015 S. Karger AG, Basel

$1015-2008 / 15 / 0822-0090 \$ 39.50 / 0$

E-Mail karger@karger.com

www.karger.com/pat
Dr. Pedro Luis Fernandez, $\mathrm{PhD}$

Department of Pathology

Hospital Clínic, Villarroel 170

ES-08036 Barcelona (Spain)

E-Mail plfernan@ clinic.ub.es 


\section{Introduction}

In spite of the relative preservation in more than $90 \%$ of natural mummies, very few studies have described the histology of mummified eyes [1]. Analysis of this organ could provide not only interesting information about the mummification process and ocular diseases in antiquity but also forensic clues regarding the cause of death.

Given the scarcity of reports on this organ, we decided to describe our histopathological findings in a mummified eye from a 35- to 38-year-old sacrificed woman belonging to the Peruvian Lambayeque culture (between 900 and 1,200 AD) from the northern coast of Peru, which showed very good preservation of soft tissues, including the seldom found optic nerve, as well as pathological signs consistent with strangulation.

\section{Case Report}

The specimen consisted of soft parts detached from the anterior aspect of the left orbit and malar region of a female individual (registry No. G2.6/91, burial No. 7/91) from the 1991 excavation of Huaca Cao Viejo [2, 3]. The sample included recognizable closed eyelids and skin on the anterior aspect (fig. 1). The posterior aspect of the specimen was very irregular, but a $10-\mathrm{mm}$ beveled cord-like structure was found to protrude close to the center (fig. 1 inset) and was interpreted as a possible optic nerve with a thickness that varied from 4 to $1.5 \mathrm{~mm}$ at the terminal part. The peripheral part of the specimen showed a harder consistency suggestive of thin bone. In toto immersion in Sandison's solution [4] for $2 \mathrm{~h}$ and fixation in formalin for $24 \mathrm{~h}$ were followed by serial transverse sectioning of the whole wet specimen. The putative optic nerve was also sectioned transversally. Sections thus obtained were subjected to routine histopathological processing through paraffin embedding and microtome sectioning. Hematoxylin-eosin staining was performed on 3 - to 4 - $\mu$ m sections. A $3 \times 3 \times 2 \mathrm{~mm}$ sample of the nerve was also submitted for scanning microscopy. The rehydrated and formalin-fixed fragment was allowed to dry for 7 days and examined uncoated using a low vacuum electron microscope (ESEM-Quanta 200; FEI).

Soft parts of the specimen from the face showed good preservation macroscopically, including the left ocular area which was histopathologically analyzed.

The eyelids had a well-preserved structure in which the tarsal dermis, striated muscle, and palpebral glands were easily recognized (fig. 2a, b).

The eyeball showed good preservation of the sclera, which had a maximum thickness of approximately $430 \mu \mathrm{m}$ (fig. 2c). In the inner third of this structure, a brown pigment consistent with choroidal melanin was easily observed (arrow in fig. $2 \mathrm{~d}$ ). Neither the lens nor the retinal epithelium could be recognized. Contrarily, the histology of both the transversal sections of the putative optic nerve and some of the sections crossing the full specimen at approximately the center was consistent with the former. Indeed, parallel compartments separated by a thick wall were interpreted

Histopathology of a Mummified Eye

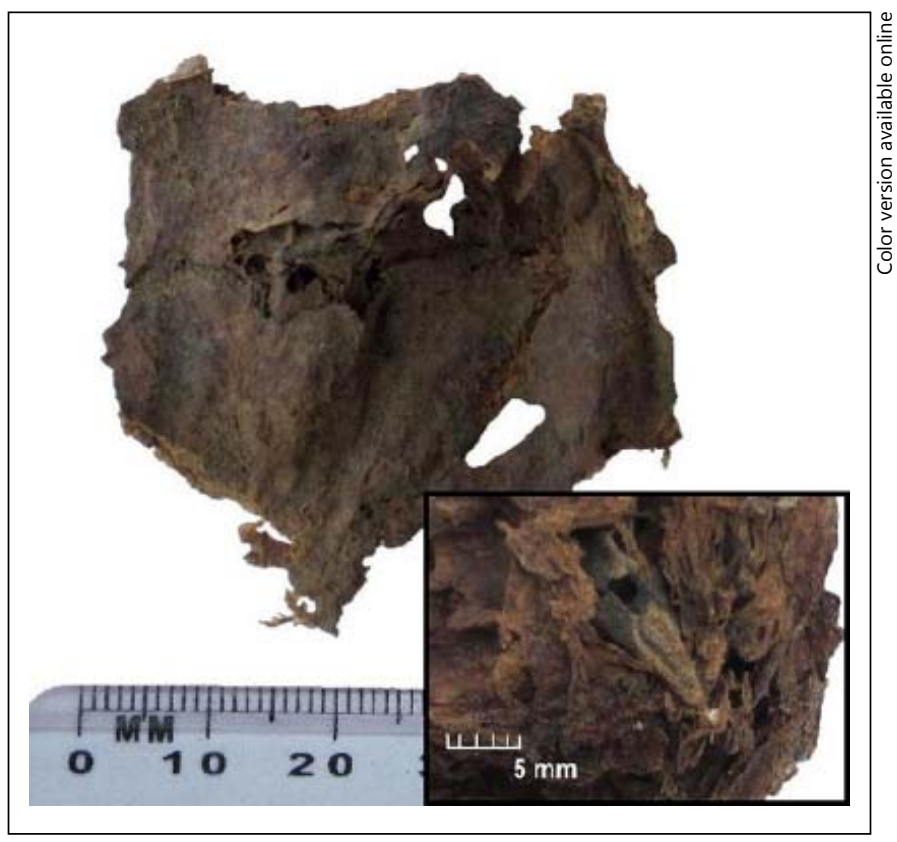

Fig. 1. The specimen analyzed consisted of soft parts from the anterior left-malar area which included a closed eye. The posterior aspect of the specimen showed a $10-\mathrm{mm}$ beveled cord-like structure consistent with the optic nerve (inset) which measured 1.5$4 \mathrm{~mm}$ in diameter.

as nerve fascicles which surrounded elongated hollow structures most likely corresponding to central retinal vessels (fig. 2e). Interestingly, abundant extravasated erythrocytes were found in some areas of the nerve, consistent with hemorrhage (fig. $2 \mathrm{f}$ ). The average thickness of the nerve, including the meningeal cover, was $3 \mathrm{~mm}$ after histological processing. Scanning electron microscopy showed meningeal covers around the end of the structure (fig. $2 \mathrm{~g}$ ) and longitudinal structures on the surface, consistent with nerve fibers (fig. 2h). Other orbital tissues such as fragments of bone and adipose tissue (fig. $2 \mathrm{i}$ ) were easily recognized.

\section{Discussion}

The Lambayeque culture, also known as Sican, developed on the northern coast of Peru in the Andes cultural area. Several Lambayeque burials are documented in Huaca Cao Viejo of the El Brujo complex belonging to the era of main extension and territorial influence (900-1,200 AD) [2]. Like other Andean cultures, the Lambayeque seem to have practiced ritual sacrifices of both male and female subjects who were close to important individuals, thus continuing their links after death $[2,3]$. This is also the case for cultures such as the Inca, Moche, Nasca, and Wari, with different rituals, including the transformation of heads into trophies, and goals such as worshiping the 


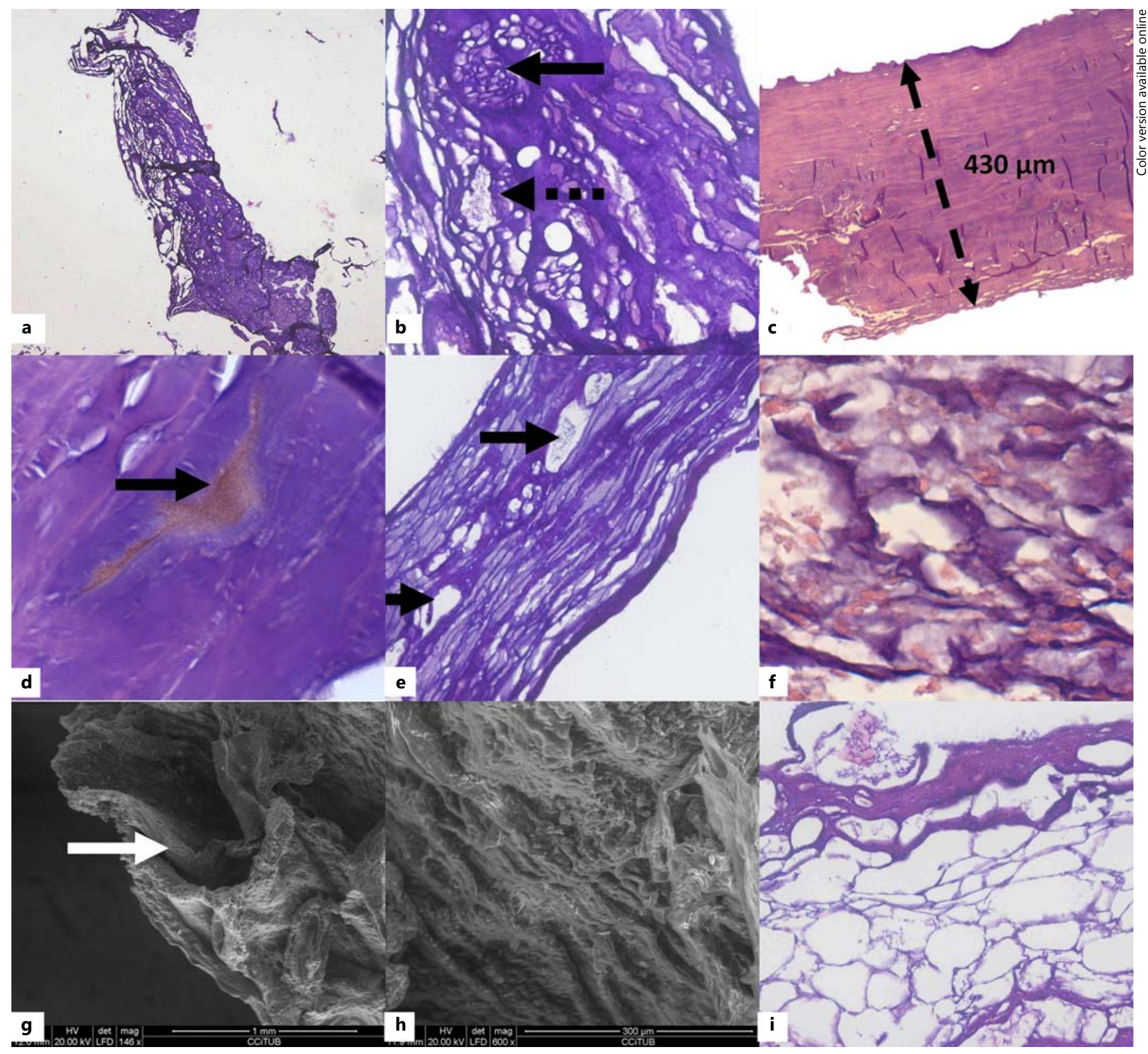

Fig. 2. a Low-power view of the eyelid. b Muscle bundles (solid arrow) and palpebral glands (dotted arrow) can be recognized. c Sclera. Histology shows a thick structure composed of parallel membranous layers measuring more than $400 \mu \mathrm{m}$. d Melanin-containing cell in the inner aspect of the sclera. e Longitudinal section of the optic nerve showing parallel structures consistent with nerve

mountains, marking significant political events or providing a powerful status [5-10]. This knowledge has helped to provide a better understanding of the motivations behind sacrificial rituals and social practices in the ancient populations of the Andes. The Lambayeque subject de- fibers and central vessels (arrows). $\mathbf{f}$ Infiltration of nerve fibers by erythrocytes indicating optic nerve hemorrhage. $\mathbf{g}$ Scanning electron microscopy of the optic nerve showing laminar structures (arrow) around the nerve fibers consistent with meningeal covers. h Scanning electron microscopy showing longitudinal structures of the optic nerve. $\mathbf{i}$ Adipose tissue surrounding the globe.

scribed here was strangled with a cotton noose that was still in place when the subject was studied, and she might correspond to a concubine of a subject of high status.

There are rare histological descriptions of mummified eyes, with those of optic nerves being even less frequent. 
Previous reports of ocular structures include some pathological findings with potential historical consequences. For instance, Salo et al. [11] identified Mycobacterium tuberculosis in the eye of a 1,000-year-old Peruvian mummy, providing convincing evidence of the preexistence of tuberculosis in the New World prior to the arrival of Christopher Columbus. Other descriptions of infectious conditions include Chagas' disease in mummies from the Atacama Desert [12]. On histological analysis of ocular tissues from mummified Eskimo children from Qilakitsoq, other authors were able to identify eyelid, sclera, lens and pigment, but not the optic nerve [13]. Holz et al. [14] recently reported their findings in 2 mummified eyes from the Atacama Desert with very good preservation of the sclera, lens, uvea, and folded segments of pigment epithelia. Contrary to expectations, Egyptian mummies rarely provide well-preserved eyes for histopathological analysis, since embalmers usually made no attempt to preserve them and often replaced the eyes with materials such as linen, shells, artificial eyes, or even onions (!) [15, 16].

Our study provides detailed histological features of some of the structures of an Andean pre-Columbian mummified eye, including the elusive optic nerve, as well as some technical approaches such as scanning electron microscopy which we consider useful for the processing and study of this organ. Of special interest are the signs of hemorrhage that we found in the optic nerve, which are consistent with strangulation as the cause of sudden intracranial hypertension and subsequent venous stasis with rupture of the central retinal vein or its tiny collaterals on the pia of the optic nerve $[17,18]$. This is, to our knowledge, the first time that such a finding has been reported in ancient mummified tissue and, together with our previous study of a 3,000-year-old brain [19], it shows that histological analysis can be performed on fragile naturally mummified nervous tissues after adequate rehydration. We also believe that the findings and methods presented here could help in the evaluation of modern cases of potential strangulations by careful analysis of ocular structures.

We conclude that the procedures described here allow morphological and forensic studies which can help to better understand the mummification process as well as detect ancient pathological findings or forensic clues in rarely preserved organs such as the eye, in which several structures are often amenable to macro- and microscopic evaluation.

\section{References}

1 Aufderheide AC: Soft tissue paleopathology: diseases of the viscerae; in Aufderheide AC (ed): The Scientific Study of Mummies. Cambridge, Cambridge University Press, 2003, pp 418-499.

2 Franco R, Gálvez C: Muerte, identidades y prácticas funerarias post Mochicas en el Complejo El Brujo, Valle de Chicama, costa norte del Perú: muerte y evidencias funerarias en los Andes Centrales - avances y perspectivas. Actas II Semin Arqueología UNFV, Lima, 2005, pp 78-118.

3 Franco R, Galvez C: Muerte, iconografía e identificación de roles de personajes de la elite Mochica en Huaca Cao Viejo, Complejo El Brujo; in Valle L (ed): Arqueología y desarrollo: experiencias y posibilidades en el Perú. Trujillo, Ediciones SIAN, 2010, pp 79-102.

4 Sandison AT: Reconstitution of dried-up tissue specimens for histological examination. J Clin Pathol 1966;19:522-523.

5 Verano J: Advances in the paleopathology of Andean South America. J World Prehist 1997; 11:237-268.

6 Reinhard J: Ice Maiden: Inca Mummies, Mountain Gods, and Sacred Sites in the Andes. Washington, National Geographic, 2006.

7 Wilson AS, Andrew S, Ceruti MC, Chavez JA, Reinhard J, Grimes V, Meier-Augenstein W, Cartmell L, Stern B, Richards MP, Worobey
M, Barnes I, Gilbert MT: Stable isotope and DNA evidence for ritual sequences in Inca child sacrifice. Proc Natl Acad Sci U S A 2007; 104:16456-16461.

8 Tung TA, Knudson KJ: Childhood lost: abductions, sacrifice, and trophy heads of children in the Wari empire of the ancient Andes. Lat Am Antiq 2010;21:44-66.

9 Besom T: Inka Human Sacrifice and Mountain Worship: Strategies for Empire Unification. Albuquerque, University of New Mexico Press, 2013.

10 Turner BL, Klaus HD, Livengood SV, Brown LE, Saldaña F, Wester C: The variable roads to sacrifice: isotopic investigations of human remains from Chotuna-Huaca de los Sacrificios, Lambayeque, Peru. Am J Phys Anthropol 2013;151:22-37.

11 Salo WL, Aufderheide AC, Buikstra J: Identification of Mycobacterium tuberculosis DNA in a pre-Columbian Peruvian mummy. Proc Natl Acad Sci U S A 1994;9:2091-2094.

12 Aufderheide AC, Salo W, Madden M, Streitz J, Buikstra J, Guhl F, Arriaza B, Renier C, Wittmers LE Jr, Fornaciari G, Allison M: A 9,000year record of Chagas' disease. Proc Natl Acad Sci U S A 2004;101:2034-2039.

13 Andersen SR, Prause JU: Histopathological examination of eyes; in Hart Hansen JP,
Gull $\varphi v$ HC (eds): Man and Society: the Mummies of Qilakitsoq Eskimos in the 15th Century. Copenhagen, Meddelelser om Grenland, 1989, pp 109-111.

14 Holz HA, Lloyd WC 3rd, Mannis MJ, Aufderheide AC: Histopathologic findings in naturally preserved mummified human eyes. Arch Ophthalmol 2007;125:978-981.

15 Sandison AT: The eye in the Egyptian mummy. Med Hist 1957;1:336-339.

16 Andersen SR: The eye and its diseases in Ancient Egypt. Acta Ophthalmol Scand 1997;75: 338-344.

17 Muller PJ, Deck JH: Intraocular and optic nerve sheath hemorrhage in cases of sudden intracranial hypertension. J Neurosurg 1974; 41:160-166.

18 Leetsma JE: Forensic aspects of intracranial equilibria; in Leetsma JE (ed): Forensic Neuropathology. Boca Raton, CRC Press, 2009, pp 343-399.

19 Prats-Muñoz G, Malgosa A, Armentano N, Galtes I, Esteban J, Bombi JA, Tortosa M, Fernandez E, Jordana X, Isidro A, Fullola JM, Petit MA, Guerrero VM, Calvo M, Fernández PL: A paleoneurohistological study of 3,000-year-old mummified brain tissue from the Mediterranean Bronze Age. Pathobiology 2012;79:239-246. 